Benjamin Schmidt, Inventing Exoticism: Geography, Globalism, and Europe's Early

Modern World. Philadelphia: University of Pennsylvania Press, 2015. xix + 412 pp.

(Cloth US\$85.0o)

Inventing Exoticism: Geography, Globalism, and Europe's Early Modern World shows us that "alternative truths" are nothing new. Benjamin Schmidt makes abundantly clear that Dutch travel accounts published in the seventeenth and eighteenth centuries have to be read with caution. Admittedly, he is not the first to question the authenticity of such publications, even those based on firsthand accounts, but it is insightful to read how exaggerated or even fraudulent these texts can be. A case in point is the 1665 travel account of China edited by the Amsterdam publisher Jacob van Meurs, a large-format book based partly on the journals and on-site sketches of Johan Nieuhof, who as envoy of the Dutch East India Company had visited the imperial court in Beijing almost a decade earlier. Schmidt writes about the way "several otherwise authored texts were adopted and augmented, massaged and manipulated" (pp. 27-28) for the publication. In doing so, Van Meurs introduced a template for presenting the world in large, lavishly illustrated books filled with maps and enticing figures. Many people were involved in this type of publication, confusingly describing themselves as either the editor, publisher, printer, or seller of the book in question, not to forget the many engravers and translators hired for these projects. In many instances, it is difficult to establish precisely who should be acknowledged for the editing, which is not surprising as these books were generally a mix of already-existing texts embedded in a new narrative.

It is not only the texts of many travel accounts that should be taken with a grain of salt, but also the prints that are published in them. In the book on China published by Van Meurs (who had been trained as an engraver) almost half of the 150 illustrations were not based on Nieuhof's own drawings, but on other sources, including the imagination of the involved engravers themselves! Significantly, many of these images produced by Dutch publishing houses had a long afterlife. When some of them ended up in pattern books for decorative arts or were used as a source for hand-painted earthenware, their original context had generally been lost. In fluid prose and with many examples, Schmidt describes how exoticism was invented by Europeans and how, in doing so, they gained their own identity. Inventing Exoticism highlights the way the new notion of Europe on the one hand and the "exotic" world on the other came to fruition during a pivotal moment of European expansion in the world.

This richly illustrated book deals not only with many printed sources and their imagery—not all of them familiar to art historians — but also with some

(C) QUENTIN BUVELOT, 2019 | DOI:10.1163/22134360-09301003

This is an open access article distributed under the terms of the prevailing CC-BY-NC license 
well-known images that are related to "Dutch Brazil" and should therefore be regarded as part of Caribbean history. It was the Dutch governor Johan Maurits of Nassau-Siegen who had Albert Eckhout paint the inhabitants of Holland's colony in North-eastern Brazil, and Frans Post its landscapes. Via Johan Maurits their drawings came into the hands of publishers in the Netherlands, serving as models for many engravings and woodcuts. These images were used for countless illustrated books on Brazil and South America. The Brazilian imagery of Post and Eckhout also inspired a famous series of tapestries produced in France after Johan Maurits had gifted Brazilian paintings to the French king, Louis XIV. I would stress that one has to remain cautious with describing the material made by the artists working for Johan Maurits, as he clearly had a political agenda of his own. On the basis of inscriptions on the paintings themselves it is generally assumed that Eckhout's eight canvasses of life-sized "Brazilians," wrongly described by Schmidt as "portraits" (p. 187), were made in Brazil in the early 1640 . However, this is less than certain, and regardless of whether they were painted in Brazil or Europe, they are not portraits in the true sense of the word. This is evident when one compares the painting of a black woman discussed in Chapter 3 with its preparatory drawing in Krakow, reproduced in Chapter 4 (fig. 166). The figure posing for the drawing was without doubt an enslaved woman from Africa who worked on Dutch plantations in Brazil-the description of this woman as an "African 'Venus'" (pp. 188, 191) is erroneous. Despite the many realistic details, the painting in question should be seen as an assemblage made in Eckhout's studio based on what he had seen in situ. This interpretation actually proves the point of Schmidt's impressive book. With their extreme attention to detail the Dutch managed to invent a convincing image of the world outside Europe.

\section{Quentin Buvelot}

Curatorial Department, Mauritshuis, The Hague

q.buvelot@mauritshuis.nl 